\title{
Molecular basis of the anti-inflammatory potential of a diarylheptanoid in murine macrophage RAW 264.7 cells
}

\author{
Bharathi Raja Rajaganapathy ${ }^{1}$, Karthikeyan Thirugnanam ${ }^{1}$, Muthusamy Velusamy Shanmuganathan ${ }^{1,2}$, \\ Anand Singaravelu ${ }^{1}$, Lakshmi Baddireddi Subadhra ${ }^{1 *}$
}

\footnotetext{
${ }^{1}$ Tissue Culture and Drug Discovery Lab, Centre for Biotechnology, Anna University, Chennai, India

${ }^{2}$ National Institute of Nutrition (Indian Council of Medical Research), Hyderabad, India

Email: "bharathicbt@gmail.com
}

Received 9 November 2013; revised 29 November 2013; accepted 5 December 2013

Copyright (C) 2013 Bharathi Raja Rajaganapathy et al. This is an open access article distributed under the Creative Commons Attribution License, which permits unrestricted use, distribution, and reproduction in any medium, provided the original work is properly cited.

\begin{abstract}
Natural products play a significant role in human health in relation to the prevention and treatment of inflammatory disorders. In this study, we examined the molecular basis of the anti-inflammatory potential of a diarylheptonoid (DAH) isolated from Alpinia officinarum hexane extract (AOHE) with special emphasis on their ability to modulate the nuclear factor-KB (NF-KB) signaling involved in the inflammatory response. Measurement of Nitrite by Griess reaction which revealed the effect of DAH in RAW 264.7 macrophages showed an inhibition in the nitric oxide production through the suppression of inducible nitric oxide synthase (iNOS) gene level expression. NF-KB reporter gene assay suggests inhibition of NFкB transcriptional activity, thus inhibiting LPS-induced phosphorylation and degradation of IKB $\alpha$ and a downregulation of NF-KB protein expression confirms the immunomodulatory effect of DAH. Furthermore, downregulation in the gene level expression of NF-KB signaling markers such as IL-1 $\beta$, TNF- $\alpha$ and COX-2 suggests the anti-inflammatory potential of DAH via inhibition of NF-KB activation.
\end{abstract}

Keywords: Diarylheptanoid; NF-кB; Lipopolysaccharide; TNF- $\alpha$; COX-2; iNOS; Cytokines

\section{INTRODUCTION}

Macrophages, vital components of the innate immune system, perform a major role in acute inflammatory responses. Lipopolysaccharide (LPS) stimulated macrophages generate a variety of inflammatory mediators, such as nitric oxide (NO), prostaglandin E2 (PGE2), in-

"Corresponding author. terleukin $1 \beta$ (IL-1 $\beta$ ) and tumor necrosis factor alpha $(\mathrm{TNF}-\alpha)$ [1]. NO generation plays a critical role in a variety of pathophysiological conditions, including inflammation and carcinogenesis [2]. iNOS, an isoform of NO synthase, is expressed in the response to a variety of inflammatory stimuli and generates high levels of NO in macrophages during the inflammatory condition [3]. Therefore, NO production might be reflective of the inflammation process and may provide a measure to assess the effect of anti-inflammatory drugs.

$\mathrm{NF}-\mathrm{KB}$ is one of the most ubiquitous transcription factors and regulates the genes involved in cellular proliferation, inflammatory responses and cell adhesion. Functionally, active NF-KB exists mainly as a heterodimer comprised of subunits of the Rel family p50 and p65, which is normally sequestered in the cytosol as an inactive complex due to its binding with inhibitors of $\kappa B$ (IкBs) in unstimulated cells [4]. The activation of NF-кB involves in the phosphorylation of IKBs at two critical serine residues (Ser 32, Ser 36) via the ІкB kinase (IKK) signalosome complex [5]. Once IKBs have been phosphorylated, they are ubiquitinated and degraded by $26 \mathrm{~S}$ proteosome. The resulting free NF- $\mathrm{KB}$ is then translocated to the nucleus, where it binds to кB-binding sites in the promoter regions of target genes and induces the transcription of proinflammatory mediators [6]. The inappropriate activation of NF- $\mathrm{KB}$ and the systemic inflammatory response has been attributed to TNF- $\alpha$ and its superfamily members such as IL-6 and IL-8 [7]. TNF$\alpha$ plays a key role in induction and perpetuation of inflammation due to autoimmune reactions by activating $T$ cells and macrophages by up-regulating the other proinflammatory cytokines [8]. iNOS and COX-2 expression are also regulated by NF-KB and COX2 produces large quantities of pro-inflammatory PGs at the inflammatory site and formed PGs mediate pain and inflammation [9]. 
Thus inhibitions in the overproduction of NO production in macrophages through inhibiting iNOS and COX-2 expressions or their activities may have therapeutic potential in the development of anti-inflammatory drugs [10]. LPS-stimulated macrophages also activate several intracellular signaling pathways, including the NF-KB pathway, mitogen-activated protein kinase (MAPK) pathways and c-Jun N-terminal kinase (JNK) [11].

Alpinia officinarum is a traditional medicinal plant used for treating inflammatory and gastrointestinal disorders. It belongs to the Zingiberaceae family, which includes other important medicinal plants such as $\mathrm{Cur}$ cuma longa and Zingiber officinale with well-documented medicinal properties. Diarylheptanoids from Alpinia officinarum are phenolic compounds that exhibit anti-inflammatory, anti-cancer and anti-bacterial properties [12]. Herein, we report an alternative approach to the development of novel therapeutics based on the endogenous mediators and mechanisms that switch off inflammation. Therefore, we have evaluated the anti-inflammatory effects of DAH isolated from the rhizome part of Alpinia officinarum hexane extract on the production of $\mathrm{NO}$ in LPS-induced murine RAW 264.7 macrophages. Our results demonstrate that DAH inhibits the production of $\mathrm{NO}$ and downregulates the inflammatory mediators through inhibition of NF-KB transactivation.

\section{MATERIALS AND METHODS}

\subsection{Cell Culture}

The murine macrophage cell line RAW 264.7 were purchased from NCCS, Pune, India and cultured in Dulbecco's modified Eagle's medium (DMEM, GIBCO Inc, NY, USA) $10 \%$ Fetal bovine serum (FBS) and RPMI 1640 medium containing 10\% FBS supplemented with penicillin (120 units $/ \mathrm{mL})$, streptomycin $(75 \mu \mathrm{g} / \mathrm{mL})$, gentamycin $(160 \mu \mathrm{g} / \mathrm{mL})$ and amphotericin B $(3 \mu \mathrm{g} / \mathrm{mL})$. Cells were maintained in a humidified atmosphere with $5 \% \mathrm{CO}_{2}$ at $37^{\circ} \mathrm{C}$ and were sub-cultured in every three days.

\subsection{Extraction, Fractionation, Structural Characterization}

An authenticated, dried, pulverized rhizome powder of Alpinia officinarum (100 g) was subjected to sequential extraction using organic solvents of increasing polarity such as hexane, ethyl acetate and methanol by Soxhlet extraction technique. The extracts obtained were designnated as Alpinia officinarum hexane extract (AOHE), Alpinia officinaru methyl acetate extract (AOEAE) and Alpinia officinarum methanol extract (AOME). The extracts were then subjected to TLC analysis using hexane: ethyl acetate (8:2) as mobile phase. Based on the preliminary results AOHE (5 g) was subjected to solvent- solvent fractionation by dissolving it in $70 \%$ methanol. The soluble portion of AOHE in $70 \%$ methanol was partitioned with hexane and chloroform. Based on the antiinflammatory activity, the hexane soluble fraction was selected for column purification which was performed using a gradient mixture of hexane: ethyl acetate as the mobile phase using silica gel (60-120 mesh size) as adsorbent. As a result of column fractionation, sub fractions were collected and based on the anti-inflammatory activity, sub fraction 3 on further purification yielded a pure molecule.

The mass spectra confirmed the elemental composition of the compound. The structure of the active molecule was determined by ${ }^{1} \mathrm{H},{ }^{13} \mathrm{C}$ nuclear magnetic resonance spectroscopy. The structural characterization details are as follows: ${ }^{1} \mathrm{H}$ NMR $(\mathrm{CDCl} 3,500 \mathrm{MHz})$ : d 2.50 (2H, H-6), $2.74(\mathrm{H}-7), 2.78$ (2H, H-2), $2.82(2 \mathrm{H}, \mathrm{H}-1)$, $4.58(\mathrm{br} \mathrm{s}, 1 \mathrm{H}, \mathrm{OH}), 6.08(1 \mathrm{H}, \mathrm{H}-4), 6.72(2 \mathrm{H}, \mathrm{H}-3$ ', H-5'), 6.81 (1H, H-5), 7.02 (d, H-2', H-6'), 7.15 (d, 2H,H-2", H-6"), 7.19 (br, 1H, H-4"), 7.27 (br, 2H, $\mathrm{H}-3$ " , H-5"); ${ }^{13} \mathrm{C}$ NMR (CDCl3, $\left.100 \mathrm{MHz}\right)$ : d 29.2 (C-1), 34.0 (C-6), 34.3 (C-7), 41.9 (C-2), 115.2 (C-3', C-5'), 126.1 (C-4"), 128.2 (C-2", C-6”), 128.4 (C-3", C-5"), 129.4 (C-2', C-6'), 130.6 (C-4), 133.3 (C-1'), 140.6 (C-1"), 146.2 (C-5), 153.8 (C-4'), 199.6 (C-3); ESMS $(+\mathrm{ve}):[\mathrm{M}+\mathrm{H}]+$; calculated for $\mathrm{C} 19 \mathrm{H} 20 \mathrm{O} 2+\mathrm{H}$, 280.36. The mass spectra confirmed the elemental composition of the compound.

Quantification of the isolated active molecule was done by HPTLC: The stock solution of AOHE (100 $\mathrm{mg} / \mathrm{mL}$ ) was used for TLC identification/quantification. $10 \mathrm{mg}$ of active moleculewas weighed and dissolved in $10 \mathrm{~mL}$ of methanol. $0.1 \mathrm{mg} / \mathrm{ml}$ solution was prepared by serial dilution from the above stock solution of active molecule standard $(1 \mathrm{mg} / \mathrm{ml})$ for TLC quantification. The following chromatographic conditions were applied. Stationary phase: Silica gel $\mathrm{GF}_{254}$; Mobile phase: $\mathrm{n}$-Hexane: Ethyl acetate $(8: 2 \mathrm{v} / \mathrm{v})$; Chamber saturation time: $1 \mathrm{hr}$; Instrument: HPTLC (Camag-version 1.3.4); Applicator: Linomat V; Scanner: Camag TLC scanner III; Developing chamber: Twin trough glass chamber $(20 \times 10 \mathrm{~cm})$; Developing mode: Ascending mode (multiple development); Detection scanning wavelength: $280 \mathrm{~nm}$; Experimental condition: $25+28^{\circ} \mathrm{C}$; Temp/RH: $55 \%-65 \%$. The limit of detection (LOD) and limit of quantification (LOQ) were estimated using the active compound. Quantitative analysis of AOHE was chromatographed and scanned at $546 \mathrm{~nm}$. The amount of active molecule present in AOHE was calculated by comparing the absorption units (AU) of standard active molecule.

\subsection{Measurement of Nitrite by Griess Reaction}

RAW 264.7 cells were seeded at $5 \times 10^{5}$ cells/well in 24- 
well plates and incubated with or without LPS $(1 \mu \mathrm{g} / \mathrm{mL})$ and with various concentrations $(5,10,25,50$ and 100 $\mu \mathrm{g} / \mathrm{mL}$ ) of AOHE and DAH for $24 \mathrm{~h}$. Nitrite levelswere determined using the Griess reaction [13]. Briefly, $100 \mu \mathrm{l}$ of cell culture medium was mixed with $100 \mu$ l ofGriess reagent $(1 \%$ sulfanilamide and $0.1 \%$ NEDD in $2.5 \%$ ortho phosphoric acid) and incubated at room temperature for $10 \mathrm{~min}$. The nitric oxide concentration was estimated using standard curve plotted against known quantity of sodium nitrite. Results were expressed in $\mu \mathrm{M}$ obtained from the mean OD of triplicate wells. The standard curve was plotted using different concentrations of sodium nitrite ( 1 to $100 \mu \mathrm{M}$ ) with absorbance of $570 \mathrm{~nm}$.

\subsection{Isolation of PBMC}

Heparinised venous blood was taken from 3 healthy huuman volunteers with their mutual consent. Mononuclear cells were isolated in a Ficoll-Hypaque (Pharmacia, Piscataway, NJ density gradient using standard procedures which separated PBMCs from whole blood. The buffy coat containing PBMCs was removed carefully following centrifugation and washed twice in RPMI 1640 medium containing 10\% FCS. Cells were counted and assessed for viability using MTT assay.

\subsection{Assessment of Cytotoxicity}

Cell viability was measured with the conventional MTTreduction assay. Briefly, PBMC cells were seeded in 96-well plates in $200 \mu \mathrm{L}$ of RPMI with $10 \%$ FBS. Then the culture supernatant was removed and replaced with phenol red free RPMI containing various concentrations (5 - $100 \mu \mathrm{g} / \mathrm{mL}$ ) of AOHE and DAHwhich was incubated for $24 \mathrm{~h}$. Treatment of $10 \mathrm{ul}$ Triton-x-100/ well, served as positive control for cytotoxicity. After the incubation time, MTT reagents were added and incubate for $4 \mathrm{~h}$. After incubation add $100 \mu \mathrm{L}$ of DMSO and read the plates at $490 \mathrm{~nm}$ on a scanning multi-well spectrophotometer and expressed as \% of vehicle treated control [14].

\subsection{Western Blot Analysis}

RAW 264.7 cells were incubated with or without LPS (1 $\mu \mathrm{g} / \mathrm{mL}$ ) and with the optimized dose of AOHE and DAH, the cells were collected and washed twice with ice cold PBS (phosphate buffered Saline). The lysis of cells were done in a lysis buffer [50 mMTris- $\mathrm{HCl}(\mathrm{pH} 7.5), 150$ mMNaCl, 1\% Nonidet P- 40, 2 mMEDTA, 1 mM EGTA, $1 \mathrm{mM} \mathrm{NaVO}_{3}, 10 \mathrm{mMNaF}, 1 \mathrm{mMdithiothreitol,} 1 \mathrm{Mm}$ phenylmethylsulfonyl fluoride, $25 \mu \mathrm{g} / \mathrm{mL}$ aprotinin, 25 $\mu \mathrm{g} / \mathrm{mL}$ leupeptin] and kept on ice for $30 \mathrm{~min}$. The cell lysates were centrifuged at $12,000 \mathrm{rpm}$ at $4{ }^{\circ} \mathrm{C}$ for $30 \mathrm{~min}$ and the supernatant were stored at $-70^{\circ} \mathrm{C}$. Protein con- centration was measured by Bradford's method. Aliquots of the lysates (100 $\mu \mathrm{g}$ of protein) were separated on a $10 \%$ SDS-polyacrylamide gel and transferred onto a nitrocellulose membrane with a glycine transfer buffer [192 mM glycine, 25 mMTris- $\mathrm{HCl}$ (pH 8.8), 20\% $\mathrm{MeOH}(\mathrm{v} / \mathrm{v})]$. After blocking the nonspecific site with $5 \%$ nonfat dried milk with PBS, the membrane was incubated with specific primary and secondary antibody. The chromogenic substrate NBT/BCIP was used for the band development.

\subsection{Transient Transfection and Luciferase Assay}

RAW 264.7 cells were seeded into $24-$ well plates $(5 \mathrm{x}$ $10^{5}$ cells/well) and allowed to grow up to $50 \%-70 \%$ confluence. The pNF-кB-luciferase plasmid was transfected with Lipofectamine Plus TM reagent (Invitrogen, Carlsbad, CA, USA) in accordance with the manufacturer's instructions. The cells were pretreated for $1 \mathrm{~h}$ with various concentrations of AOHE and DAH and were stimulated for $6 \mathrm{~h}$ with 20 ngof TNF- $\alpha$. The cells were then collected and disrupted via sonication in lysis buffer $(25$ mMTris-phosphate, $\mathrm{pH} 7.8,2$ mM EDTA, 1\% Triton X100 , and $10 \%$ glycerol) and the cell lysates were assayed for luciferase activity with a luminometer (Promega) in accordance with the manufacturer's instructions.

\subsection{Isolation of Total RNA and Semi-Quantitative Reverse Transcription-Polymerase Chain Reaction (RT-PCR)}

RAW 264.7 cells were incubated with or without LPS (1 $\mu \mathrm{g} / \mathrm{mL})$ and with the optimized dose of AOHE and DAH incubated for $24 \mathrm{~h}$. Cells were homogenized using TRIzol ${ }^{\circledR}$ reagent and RNA was isolated by phenol-chloroform extraction. The aqueous phase containing RNA was then precipitated by adding an equal volume of isopropyl alcohol. The RNA obtained was then converted to cDNA by reverse transcription using MMLV reverse transcripttase enzyme and subjected to PCR with specific primers (Table 1). PCR products were run on $1.2 \%$ agarose gels, stained with ethidium bromide and photographed. PCR products were consistent with the predicted sizes and analysed on ethidium bromide-stained agarose gels.

\subsection{Statistical Analysis}

Statistical analysis was performed using GraphPad Prism, 4.03 (San Diego). One way analysis of variance (ANOVA) followed by Dunnett's post hoc was used for the other parameters. The data are expressed as mean \pm S.E.M and $\mathrm{P}<0.05$ was considered to be statistically significant. 
Table 1. List of gene sequences and the predicted product size (basepairs).

\begin{tabular}{clc}
\hline Primer & \multicolumn{1}{c}{ Sequence } & $\begin{array}{c}\text { Predicted } \\
\text { product } \\
\text { size (bp) }\end{array}$ \\
\hline IL-1 $\beta$ & $\begin{array}{l}\text { F-AAA CAG ATG AAG TGC TCC TTC CAG G } \\
\text { R-TGG AGA ACA CCA CTT GTT GCT CCA }\end{array}$ & 388 \\
TNF- $\alpha$ & $\begin{array}{l}\text { F-CGG GAC GTG CTG GCC GAG GAG } \\
\text { R-CAC CAG CTG GTT ATC TCA CAG CTC }\end{array}$ & 156 \\
COX-2 2 & $\begin{array}{l}\text { F-TTC AAA TGA GAT TGT GGG AAA ATT GCT } \\
\text { R-AGA TCA TCT CTG CCT GAG TAT CTT }\end{array}$ & 305 \\
iNOS & $\begin{array}{l}\text { F-CTA CCT ACC TGG GGA ACA CCT GGG } \\
\text { R-GGA GGA GCT GAT GGA GTA GTA GCG C }\end{array}$ & 442 \\
GAPDH & F-CCA CCC ATG GCA AAT TCC ATG GCA & \\
R-TCT AGA CGG CAG GTC AGG TCC ACC & 356 \\
\hline
\end{tabular}

\section{RESULTS}

\subsection{Bioassay Guided Fractionation, Purification and Quantification of DAH in AOHE}

The rhizome of Alpinia officinarum was sequentially extracted successively using hexane, ethyl acetate and methanol. The extraction yield was found to be $0.224 \%$ $\mathrm{w} / \mathrm{w}, 0.512 \% \mathrm{w} / \mathrm{w}, 0.28 \% \mathrm{w} / \mathrm{w}$ respectively. After solventsolvent fractionation and based on the anti-inflammatory activity, the hexane soluble fraction was subjected to column chromatography leading to the isolation of a pure molecule. Structural characterization using NMR and mass spectral analysis led to the identification of the major chemical constituent from the active fraction to be1-(4-Hydroxyphenyl)-7-phenyl-hept-4-en-3-one (DAH) with the molecular formula $\mathrm{C}_{19} \mathrm{H}_{20} \mathrm{O}_{2}$ (molecular weight - 280.36) (Figure 1). The characteristic color of the compound is yellow and was observed to be oily in nature. The chromatographic analysis of AOHE and isolated pure molecule (DAH) was carried out at $546 \mathrm{~nm}$ and photographed. The purity of the DAH isolated from AOHE was confirmed by comparing the UV absorption spectra at the start, middle, and end position of the bands. The identity of the bands of DAH in the AOHE was confirmed by overlaying their UV absorption spectra with those of the isolated DAH. The amount of DAH present in AOHE was found to be $0.81 \% \mathrm{w} / \mathrm{w}$ (dry wt.basis).

\subsection{Effect of AOHE and DAH on Nitrite Release}

Nitric oxide release was assessed in RAW 264.7 macrophages to check the effect of AOHE and DAH on pro inflammatory mediators. The cells were stimulated with LPS $(1 \mu \mathrm{g} / \mathrm{mL})$ and treated with different concentrations of AOHE and DAH ranges from $5 \mu \mathrm{g} / \mathrm{mL}$ to $100 \mu \mathrm{g} / \mathrm{mL}$ to check the anti-inflammatory effect. The results suggested that AOHE and DAH showed a significant decrease in the nitric oxide production when compared to
LPS treated control cells at $24 \mathrm{~h}$. The $\mathrm{IC}_{50}$ of AOHE was found to be $25 \mu \mathrm{g} / \mathrm{mL}$ and for DAH $10 \mu \mathrm{g} / \mathrm{mL}$ respectively (Figure 2). The $\mathrm{IC}_{50}$ values were used for the further molecular mechanism studies.

\subsection{Cytotoxicity Effect of AOHE and DAH in PBMC}

LDH release was measured quantitatively in PBMC at 24 h using a cytotox 96 assay kit and the results are expressed as \% cytotoxicity with respect to control (untreated cells) and Triton-X-100 was used as positive control. Treatment of AOHE and DAH with RAW264.7 cells at various concentrations showed a minimal $\mathrm{LDH}$ release and the cytotoxicity was less than $20 \%$ at the highest concentration tested. The results clearly showed that AOHE and DAH have no toxic effects to RAW 264.7 cells (Figure 3).

\subsection{Effect of AOHE and DAH on NF-кB Inhibition and $\mathrm{I} \kappa \mathrm{B} \alpha$ Degradation}

To investigate whether AOHE and DAH could affect the nuclear translocation of NF- $\mathrm{KB}$, western blot analysis was conducted to check the NF-кB expression and IкB $\alpha$ degradation in RAW264.7 cell lysates. The amount of NF-кB p65 was markedly increased upon exposure to LPS treated cells, whereas AOHE and DAH inhibited NF-кB activation by downregulating the protein level expression of NF-кB (Figure 4). Furthermore, AOHE and DAH significantly upregulated IкB $\alpha$ expression suggests that inhibition of NF-кB activation by ІкВ $\alpha$ degradation.

\subsection{Effect of AOHE and DAH on NF-кB Transcriptional Activity in RAW 264.7 Cells}

To understand the effect of AOHE and DAH on NF-KB transcriptional activity, RAW264.7 cells were transiently transfected with a plasmid harboring four tandem copies of the NF-кB consensus sequence linked to the luciferase gene. Luciferase assays were performed by using the Dual-Luciferase Reporter System (Promega), in which relative luciferase activities were calculated by normalizing transfection efficiency according to the Renilla luciferase activitiy. NF-KB transcriptional activity was measured as luciferase activity with a luminometer. Inhibition in the TNF- $\alpha(20 \mathrm{ng})$ induced promoter activation of NF-кB confirms the potential inhibitory effect of AOHE and DAH by showing an inhibition in the reporter activity when compared with TNF- $\alpha(6 \mathrm{~h})$ exposed cells (Figure 5). These results indicate that AOHE and DAH inhibits NF-кB transactivation which reflects in the down regulation of the pro-inflammatory mediators. 


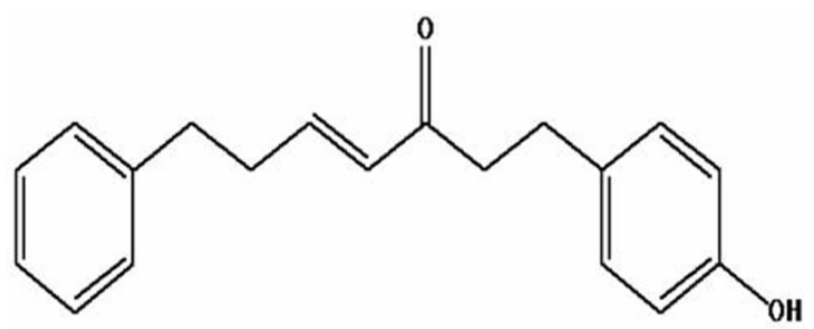

Figure 1. Structure of the bioactive compound chemically characterized as 1-(4 Hydroxyphenyl)-7-phenyl-hept-4-en-3one with molecular formula $\mathrm{C}_{19} \mathrm{H}_{20} \mathrm{O}_{2}$ (molecular weight: 280.36) and identified as Diarylheptanoid (DAH).

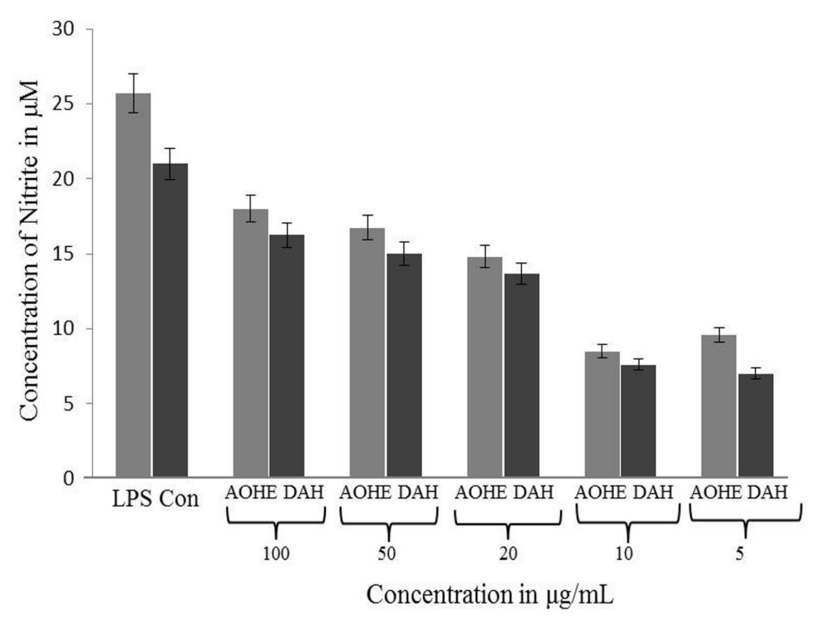

Figure 2. Dose response analysis of AOHE and DAH using Griess reaction. Cells were stimulated with $1 \mu \mathrm{g} / \mathrm{mL}$ of LPS and after 24 hours incubation the effect of AOHE and DAH on NO production was evaluated. Nitrite concentrations were reduced in a dose response manner and are expressed in $\mu \mathrm{M}$. The results are mean \pm SEM of 3 independent experiments.

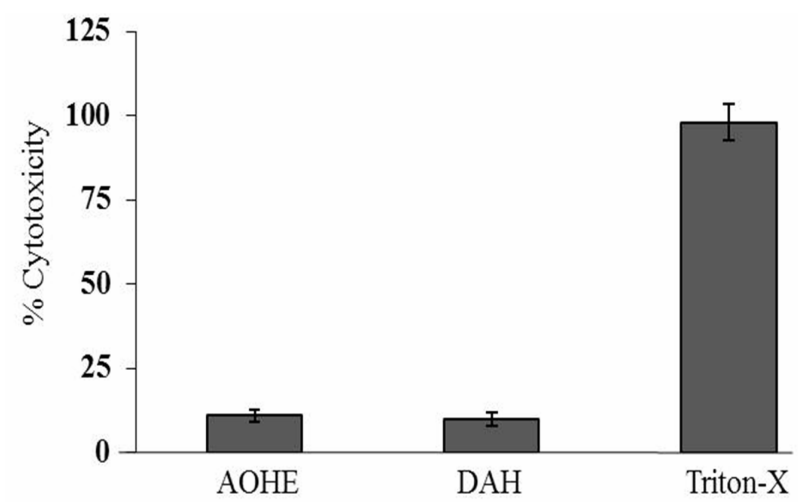

Figure 3. Cytotoxicity profiling on PBMC. Cells were incubated with the $\mathrm{IC}_{50}$ value of $\mathrm{AOHE}$ and DAH for $24 \mathrm{~h}$. Cytotoxicity was assessed based on the lactate dehydrogenase released into the supernatant and measured at $490 \mathrm{~nm}$. Triton$\mathrm{x}-100$ served as the positive control. LDH was measured by using the formula: \% LDH release $=($ OD Sample - OD control $) /($ OD TritonX-OD control $) \times 100$. Cytotoxicity was expressed as $\%$ of LDH release. Data presented as mean \pm SEM from three separate experiments for each data point.

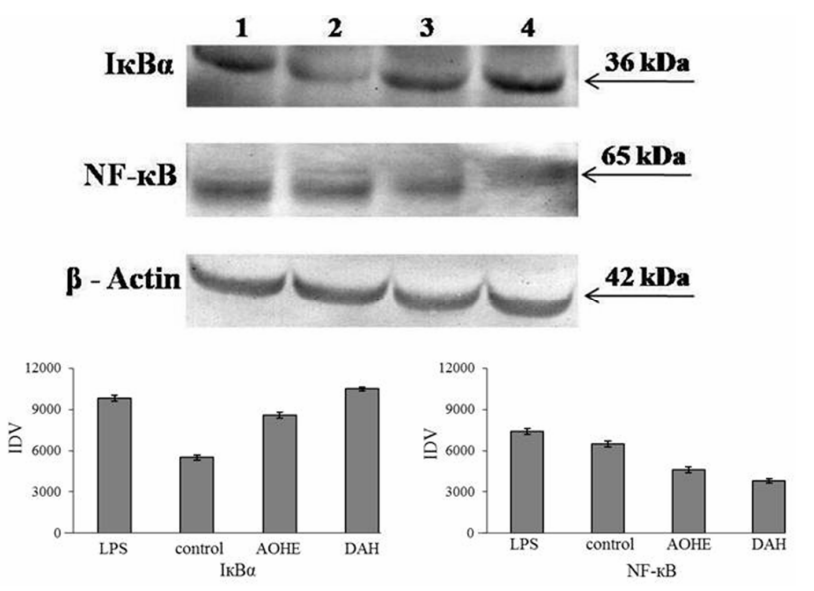

Figure 4. Analysis of AOHE and DAH on LPS induced ІкВ $\alpha$ degradation and NF-кB p65 inhibition in RAW264.7 macrophages (Lane 1-LPS control, lane 2-Control, Lane 3-AOHE, Lane 4-DAH). The densitometric band intensities have been represented as normalized IDV values.

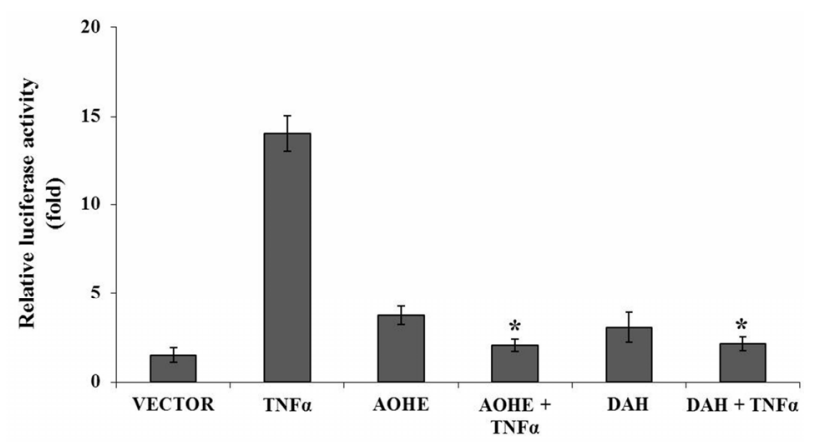

Figure 5. TNF $\alpha$-induced NF-кB-dependent reporter gene expression was observed to be inhibited by AOHE and DAH. RAW264.7 cells were transiently transfected with NF-кB-containing plasmid and treated with AOHE and DAH for $12 \mathrm{~h}$. Thereafter, cells were activated for NF-KB activation using 20 ng of TNF $\alpha$ as indicated for $6 \mathrm{~h}$. After $24 \mathrm{~h}$ the cell lysate was collected and assayed. Results are expressed as fold activity of the vector control activity. Data presented as mean \pm SEM from three separate experiments for each data point.

\subsection{Inhibitory Effect of AOHE and DAH on Pro-Inflammatory Cytokines}

The release of pro-inflammatory cytokines is an important mechanism by which the immune cells regulate the inflammatory responses and contribute to various inflammatory and autoimmune disorders. Hence we checked the ability of the AOHE and DAH in LPS induced TNF $\alpha$ and IL-1 $\beta$ gene level expression in RAW 264.7 cells. The results suggest, that TNF $\alpha$ and IL- $1 \beta$ showed a decrease in the gene expression after treatment with AOHE and DAH when compared to the LPS induced control cells. Generally, COX-2 was hardly detectable in resting macrophages, but pronounced amounts of COX-2 production can be attained when cells were induced upon exposure to LPS. Incubation with AOHE and DAH showed down- 
regulation in the gene level expression of LPS induced COX-2 synthesis. Nitric oxide production is directly proportional to the expression of iNOS and we observed a downregulation in the gene level expression of iNOS after the cells were exposed with AOHE and DAH confirms the potential of AOHE and DAH which can regulates the pro-inflammatory mediators in response to inflammatory signals (Figure 6).

\section{DISCUSSION}

The inflammatory process as a sequence of events occurs in response to noxious stimuli, trauma or infection which is orchestrated by a highly modulated interaction between mediators of inflammation and inflammatory cells [15]. A large number of compounds of varied chemical structures isolated from medicinal plants had been shown to possess anti-inflammatory activity and modulates most of the inflammatory signaling. Although the etiology of most chronic inflammatory diseases remains unknown, the initiation of certain types of chronic inflammation has been associated with development of autoimmune response, which progresses to a sustained, self-perpetuated inflammation [16]. Various anti-inflammatory drugs, including antioxidants, glucocorticoids, non-steroidal anti-inflammatory drugs (NSAIDs), immunosuppressants and various plant compounds act as inhibitors of the NF-KB pathway suggesting that suppression of NF-KB dependent transcription is an essential part of their anti-inflammatory activity [17].

Experimental evidences suggest that flavonoids have been reported to be potentially inhibits or regulate the activation of transcription factors including NF- $\mathrm{KB}$, both at the stage of initiation and perpetuation of chronic inflammation [18]. Curcumin, a dietary supplement with potent anti-inflammatory and anti-tumor activities, inhibits NF-KB activation by acting on upstream pathways controlling IKK activation [19]. In this study, DAH we have isolated from Alpinia officinarum structurally resembles as curcumin analog inhibits the transcriptional activeity of NF-KB and its mediators which confirms $\mathrm{DAH}$ as a potential anti-inflammatory agent.

NO is a signaling molecule involved in a broad spectrum of pathophysiological processes such as inflammation, apoptosis, the regulation of enzyme activity and gene expression. High levels of NO are generated in response to inflammatory stimuli and mediate pro-inflammatory effects. Therefore, NO production may reflect the process of inflammation and may provide a measure for assessing the effects of drugs on the inflammatory process [20]. In this study, we have induced the cells with LPS $(1 \mu \mathrm{g} / \mathrm{mL})$ and treated with different concentration of AOHE and DAH. We have observed a significant decrease in the NO production at $24 \mathrm{~h}$ when compared with the LPS treated control cells and the $\mathrm{IC}_{50}$ value is found to be $10 \mu \mathrm{g} / \mathrm{mL}$ for AOHE and for DAH 5 $\mu \mathrm{g} / \mathrm{mL}$ respectively. The cytotoxicity data suggests that AOHE and DAH possessed no cytotoxicity effect at the maximum concentration AOHE and DAH tested in RAW264.7 macrophages. Further, the molecular level studies were conducted with the $\mathrm{IC}_{50}$ values of AOHE and DAH.

$\mathrm{NF}-\kappa \mathrm{B}$, a major transcription factor which regulates the expression of inflammation induced enzymes and cytokines and has attracted as a new target for treating
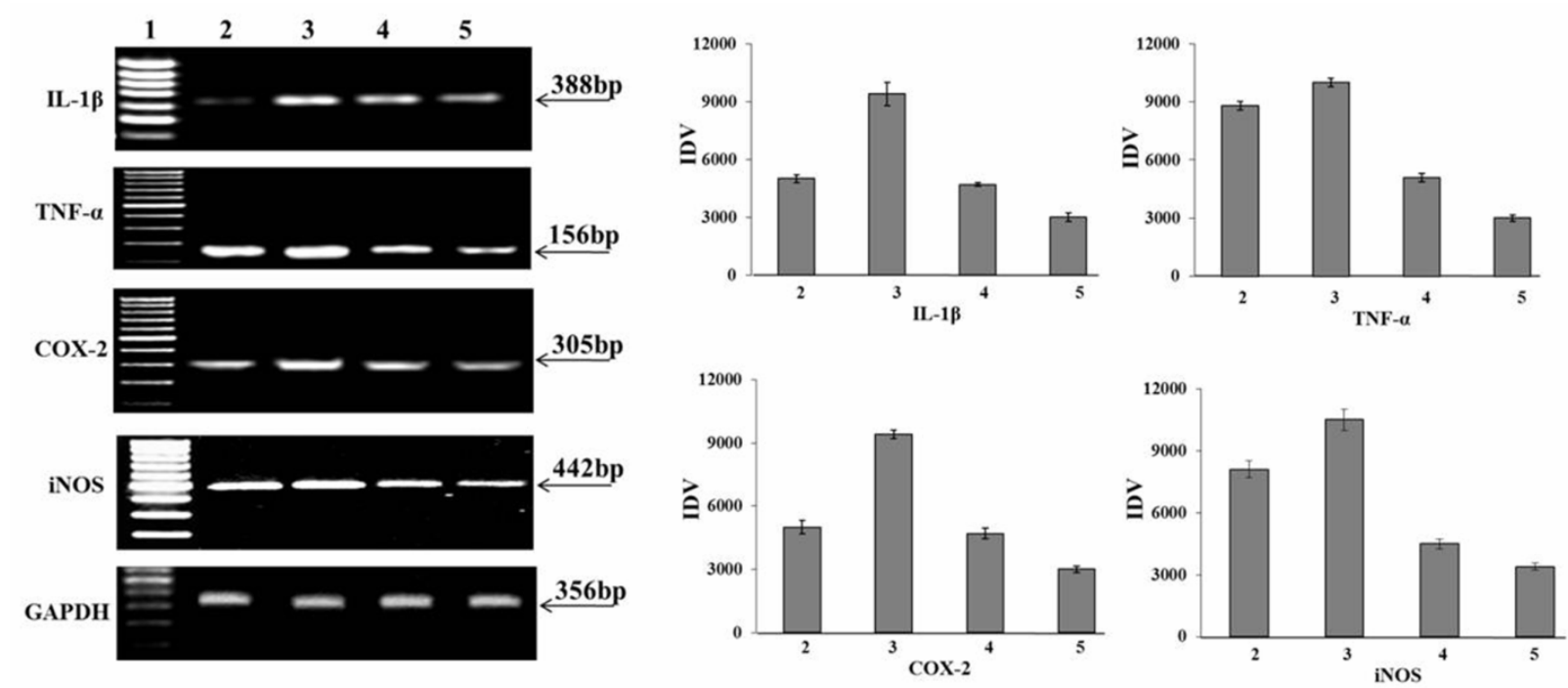

Figure 6. Effect of AOHE and DAH on IL-1 $\beta$, TNF- $\alpha$, COX-2 and iNOS gene expression in RAW264.7 cells at $24 \mathrm{~h}$. Lane 1- DNA ladder (100 bp), Lane 2- Control, Lane 3- LPS Control, Lane 4- AOHE, Lane 5- DAH. The graph shows the IDV values ratio of density of the genes expression to that of endogenous control GAPDH and represents mean \pm SEM of three replicates when compared to untreated control. 
inflammatory diseases [21]. Inactive NF-kB is localized in the cytoplasm by the inhibitor of кB (ІкB) and gets stimulated with LPS, TNF- $\alpha$ or cellular stress. Once ІкB is degraded, NF-KB will be translocated from the cytosol to the nucleus, and binds to its cognate DNA binding which activates several intracellular signaling markers Therefore, the suitable regulation of NF- $\mathrm{KB}$ may be beneficial in treating many inflammatory disorders [22]. The present study demonstrates the potential of AOHE and DAH in the LPS-induced phosphorylation and degradation of IKB and the activation and translocation of NF- $\kappa B$ p65 in LPS-stimulated RAW264.7 cells. The western blot analysis results revealed the overexpression

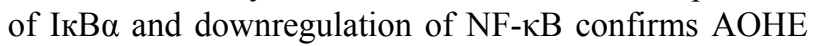
and DAH exhibits anti-inflammatory effect. Evidence for the inhibition of NF-kB signaling by AOHE and DAH in distinct mechanisms can be determined directly using a reporter gene assay. Through this concerted mechanism, AOHE and DAH blocked TNF- $\alpha$ induced NF- $\kappa$ B dependent transcription in RAW264.7 cells. The cells transfected with a plasmid containing the NF- $\mathrm{KB}$ luciferase coding region showed an inhibitory effect on RAW264.7 cells, indicates that NF- $\mathrm{kB}$ transactivation was suppressed when compared with the control which clearly shows that AOHE and DAH inhibited TNF- $\alpha$ induced NF-kB transactivation.

Pro-inflammatory cytokines such as IL- $1 \beta, \mathrm{TNF} \alpha$, and IL-6 were involved in amplification and initiation of the inflammatory process. Stimulating the cells with LPS leads to a cascade of intracellular signaling events that ultimately result in production and secretion of cytokines and other inflammatory mediators that constitute the pro-inflammatory response [23]. Hence, treatment with AOHE and DAH to LPS stimulated RAW 264.7 cells showed downregulation in the expression of TNF $\alpha$ and IL- $1 \beta$. TNF $\alpha$ and IL- $1 \beta$ also have been shown to directly regulate NO release through iNOS gene expression. Thus the inhibition of these pro-inflammatory mediators has proven to have tremendous therapeutic value of DAH. Studies revealed that nitric oxide appears to mediate or augment the synthesis of TNF $\alpha$, IL- $1 \beta$ and chemokines and a reduced gene level expression of IL- $1 \beta$ have been observed after inhibition of iNOS activation [24]. iNOS is expressed in response to a variety of inflammatory stimuli and generates high levels of NO in macrophages during the inflammatory process which was regulated by NF- $\kappa B$ [25]. Our results revealed that LPS induced reducetion in the NO production and downregulation of iNOS gene expression confirms the NF- $\mathrm{KB}$ inhibition by AOHE and DAH. COX-2, the rate-limiting enzyme in prostaglandin synthesis, is induced in many cells by inflammatory mediators [26]. Similarly observations made on AOHE and DAH treated cells demonstrated the antiinflammatory effect of AOHE and DAH was contributed by the down regulation of COX-2 expression.

\section{CONCLUSION}

This study revealed the anti-inflammatory activity of AOHE and DAH inhibited the LPS-induced expression of TNF- $\alpha$, IL- $1 \beta$, iNOS and COX-2 at gene level in RAW 264.7 cells. These suppressive effects of AOHE and DAH are mediated by inhibiting the NF- $\mathrm{KB}$ transcriptional activity. Thus, inhibition of the overproduction of NO and inhibition of NF- $\mathrm{kB}$ transcriptional activity of DAH can have a therapeutic potential in the development of anti-inflammatory drug against inflammatory diseases.

\section{ACKNOWLEDGEMENTS}

The work was supported financially by the National Medicinal Plants Board, Department of Ayurvedha, Yoga \& Naturopathy, Unani, Siddha and Homeopathy (AYUSH), Government of India (Grant no: GO/TN02/2009).

\section{REFERENCES}

[1] Shin, K.M., Kim, Y.H., Park, W.S., Kang, I., Ha, J., Choi, J.W., Park, H.J. and Lee, K.T. (2004) Inhibition of methanol extract from the fruits of Kochiascoparia on lipopolysaccharide-induced nitric oxide, prostaglandin E2, and tumor necrosis factor-alpha production from murine macrophage RAW 264.7 cells. Biological \& Pharmaceutical Bulletin, 27, 538-543. http://dx.doi.org/10.1248/bpb.27.538

[2] Kroncke, K.D., Fehsel, K. and Kolb-Bachofen, V. (1998) Inducible nitric oxide synthase in human diseases. Clinical \& Experimental Immunology, 113, 147-156. http://dx.doi.org/10.1046/j.1365-2249.1998.00648.x

[3] Laskin, D.L. and Pendino, K.J. (1995) Macrophages and inflammatory mediators in tissue injury. Annual Review of Pharmacology and Toxicology, 35, 655-677. http://dx.doi.org/10.1146/annurev.pa.35.040195.003255

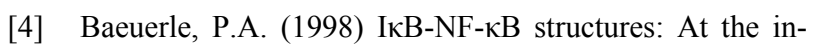
terface of inflammation control. Cell, 95, 729-731. http://dx.doi.org/10.1016/S0092-8674(00)81694-3

[5] Brown, K., Gerberger, S., Carlson, L., Franzoso, G. and Siebenlist, U. (1995) Control of IкB-alpha proteolysis by site-specific, signal-induced phosphorylation. Science, 267, 1485-1488. http://dx.doi.org/10.1126/science.7878466

[6] Didonato, J., Mercurio, F., Rosette, C., Wu, L.I., Suyang, H., Ghosh, S. and Karin, M. (1996) Mapping of the inducible IkB phosphorylation sites that signal its ubiquitination and degradation. Molecular and Cellular Biology, 4, 1295-1304.

[7] Bonizzi, G. and Karin, M. (2004) The two NF-кB activation pathways and their role in innate and adaptive immunity. Trends in Immunology, 25, 280-288. http://dx.doi.org/10.1016/j.it.2004.03.008

[8] Jirik, F.R., Podor, T.J., Hirano, T., Kishimoto, T., Los- 
kutoff, D.J., Carson, D.A. and Lotz, M. (1989) Bacterial lipopolysaccharide and inflammatory mediators augment IL-6 secretion by human endothelial cells. Journal of Immunology, 142, 144-147.

[9] Giuliano, F. and Warner, T.D. (2002) Origins of prostaglandin E2: Involvements of cyclooxygenase (COX)-1 and COX-2 in human and rat systems. Journal of Pharmacology and Experimental Therapeutics, 303, 10011006. http://dx.doi.org/10.1124/jpet.102.041244

[10] Tak, P.P. and Firestein, G.S. (2001) NF- $\kappa$ B: A key role in inflammatory diseases. The Journal of Clinical Investigation, 107, 7-11. http://dx.doi.org/10.1172/JCI11830

[11] Guha, M. and Mackman, N. (2001) LPS induction of gene expression in human monocytes. Cell Signal, 13, 85-94. http://dx.doi.org/10.1016/S0898-6568(00)00149-2

[12] Subramanian, K., Selvakkumar, C., Vinaykumar, K.S., Goswami, N., Meenakshisundaram, S., Balakrishnan, A. and Lakshmi, B.S. (2009) Tackling multiple antibiotic resistance in enteropathogenic Escherichia coli (EPEC) clinical isolates: A diarylheptanoid from Alpiniaofficinarum shows promising antibacterial and immunomodulatory activity against EPEC and its lipopolysaccharide-induced inflammation. International Journal of Antimicrobial Agents, 33, 244-250. http://dx.doi.org/10.1016/j.ijantimicag.2008.08.032

[13] Gayathri, B., Manjula, N., Vinaykumar, K.S., Lakshmi, B.S. and Balakrishnan, A. (2007) Pure compound from Boswelliaserrata extractexhibits anti-inflammatory property in human PBMCs and mousemacrophages through inhibition of TNF- $\alpha$, IL- $1 \alpha$, NO and MAP kinases. International Immunopharmacology, 7, 473-482. http://dx.doi.org/10.1016/j.intimp.2006.12.003

[14] Kim, J.Y., Jung, K.S. and Jeong, H.G. (2004) Suppressive effects of the kahweol and cafestolon cyclooxygenase-2 expression in macrophages. FEBS Letters, 569, 321-326. http://dx.doi.org/10.1016/j.febslet.2004.05.070

[15] Rosalbasacca, C., Cuff, A. and Nancy, H.R. (1997) Mediators of inflammation. Current Opinion in Immunology, 9, 851-857.

[16] Karin, M. and Ben Neriah, Y. (2000) Phosphorylation meets ubiquitination: the control of NF- $\mathrm{KB}$ activity. $A n-$ nual Review of Immunology, 18, 621-663. http://dx.doi.org/10.1146/annurev.immunol.18.1.621

[17] Epinat, J.C. and Gilmore, T.D. (1999) Diverse agents act at multiple levels to inhibit the Rel/NF- $\mathrm{KB}$ signal trans- duction pathway. Oncogene, 18, 6896-6909. http://dx.doi.org/10.1038/sj.onc.1203218

[18] Madhavan, P.N., Supriya, M., Jessica, L.R., Ravikumar, A., Harikrishnan, N., Stanley, A.S. and Chithan, K. (2006) The flavonoid quercetin inhibits proinflammatory cytokine (tumor necrosis factor alpha) gene expression in normal peripheral blood mononuclear cells via modulation of the NF- $\mathrm{kB}$ System. Clinical and Vaccine Immunology, 13, 319-328. http://dx.doi.org/10.1128/CVI.13.3.319-328.2006

[19] Jobin, C. (1999) Curcumin blocks cytokine-mediated NF$\kappa \mathrm{B}$ activation and proinflammatory gene expression by inhibiting inhibitory factor IкB kinase activity. Journal of Immunology, 163, 3474-3483.

[20] Korhonen, R., Lahti, A., Kankaanranta, H. and Moilanen, E. (2005) Nitric oxide production and signaling in inflammation. Current Drug Targets: Inflammation \& Allergy, 4, 471-479. http://dx.doi.org/10.2174/1568010054526359

[21] Haefner, B. (2002) NF-кB: Arresting a major culprit in cancer. Drug Discovery Today, 7, 653-663. http://dx.doi.org/10.1016/S1359-6446(02)02309-7

[22] Sizemore, N., Lerner, N., Dombrowski, N., Sakurai, H. and Stark, G.R. (2002) Distinct roles of the IkB kinase $\alpha$ and $\beta$ subunits in liberating nuclear factor $\mathrm{\kappa B}(\mathrm{NF}-\mathrm{\kappa B})$ from IкB and in phosphorylating the p65 subunit of NFкB. Journal of Biological Chemistry, 277, 3863-3869. http://dx.doi.org/10.1074/jbc.M110572200

[23] Gayathri, B., Lakshmi, J., Arun, B. and Baddireddi Subhadra, L. (2010) Molecular basis of the anti-inflammatory property exhibited by Cyclo-Pentano Phenanthrenol isolated from Lippianodiflora. Immunological Investigations, 39, 713-739. http://dx.doi.org/10.3109/08820139.2010.493190

[24] Angela, S., Sumikotanaka, T., Hidetakamiyoshi, T., Masaki, S., Keisuke, K. and Takahisa, S. (1997) Pathophysiological role of nitric oxide in rat experimental colitis. International Journal of Immunopharmacology, 19, 669676.

[25] Tak, P.P. and Firestein, G.S. (2001) NF- $\kappa$ B: A key role in inflammatory diseases. Journal of Clinical Investigation, 107, 7-11. http://dx.doi.org/10.1172/JCI11830

[26] Dixon, D.A. (2004) Dysregulated post-transcriptional control of COX-2 gene expression in cancer. Current Pharmaceutical Design, 10, 635-646. http://dx.doi.org/10.2174/1381612043453171 